\title{
Assessment of Resident's Attitude toward Land Acquisition for Development Activities in Thai Nguyen City, Thai Nguyen Province, Viet Nam
}

\author{
Chu Thanh Huy \\ huyct@tnus.edu.vn \\ Thainguyen University of Sciences, Tan Thinh ward, Thai Nguyen city, Thai Nguyen Provivce, Vietnam
}

\begin{abstract}
:
The article has used questionnaires which designed following five Likirt scale to measure the attitudes of 400 people living in the western area of Thai Nguyen City, Thai Nguyen Province, Vietnam toward land acquisition that may be occured in the future. Survey data that analysed by SPSS is digitized and combined with the spatial interpolation method - integrated in GIS to analyze the spatial distribution of community attitudes. The research results show that people with high education, middle-aged and female people will have more positive attitudes in land acquisition. Meanwhile, people with high incomes or jobs directly dependent on land tend to oppose land acquisition. In terms of space, very positive attitude is mainly distributed in Quyet Thang, Thinh Duc, Tan Thinh and Thinh Dan communes with an area of about 2,329 ha. Positive attitudes were mainly distributed in the east of Phuc Triu commune, the west and northeast of Quyet Thang commune, south of Tan Cuong commune, east of Thinh Duc commune with an area of about 3,376 ha. The rest is the area with less positive attitude, mainly distributed in Phuc Xuan, Phuc Triu, Tan Cuong communes with an area of about 3,339.5 ha.
\end{abstract}

Keywords: Community attitudes, land acquisition, Thai Nguyen, GIS, land use planning

\section{Introduction}

Land acquisition or land recovery in Vietnam means that the State decides to recover the land use rights by the State, or from a land user that violates the land law (Land Law, 2013). Land acquisition is an important and indispensable issue in the socioeconomic development process in all of the countries in the world. In Vietnam, land acquisition and land clearance has always been considered the biggest obstacle for large projects (Thu Hang, 2017). The phenomenon of people whose land is acquired does not comply with the decision to recover land resisting and obstructing an officer becomes popular (Dung, 2013; Lụa, 2016; Xo, 2017; Huong, 2019)... The statistics of the National Assembly show that the protracted, over-level complaints of the people are mostly related to land. In 2019, the number of lawsuits related to land accounted for 67.7\% (up 5.9\% compared to 2018) and focused mainly on issues such as land acquisition, compensation, resettlement, land disputes originating from agricultural or forestry farms, using land for national defense and security purpose, conversion of traditional markets, lawsuits, disputes in real estate projects, toll collection at BOT stations, etc. (Huong, 2019). Difficulty in land acquisition is not only a problem for Vietnam but also a common problem in many countries in the world (Hang, 2017). In Indonesia, for example, land acquisition is the main constraint in the country's infrastructure development, as commented by Yoshino et al (2019). Similarly, in India, land acquisition is also a major challenge for infrastructure development (Morris \& Pandey, 2007). In Korea, according to statistics, up to $15 \%$ of land acquisition projects must use coercive measures (P. Thao, 2013).

One of the reasons indicated when projects related to land acquisition have difficulty or even failure is that community consultation in land-use planning projects is not respected (Hien, 2013). In order to overcome shortcomings and shortcomings in land acquisition, scientists have tried to find out the attitudes, perceptions and desires of the community to answer the question of land loss that has affected the livelihoods of how do they (Hien, 2013; Thuan et al., 2018; Thủy, 2017; Khuy et al., 2014; Huong et al., 2018; Tuyen et al., 2014)... or why there is conflict between communities and stakeholders in land acquisition (Nguyen et al., 2015; Hang, 2017)...

However, most of the aforementioned studies only focus on analyzing and assessing people's psychological attitude when the project has been (or is being) implemented and research area is often on a small scale (a specific project) (Hiền, 2013; Khuy et al., 2014; Nguyen et al., 2015)... This is difficult to bring a comprehensive view, as well as long-term solutions to the problem raised. In fact, nearly all the land acquisition projects are implemented in accordance with the land law and strictly complied with the approved land use plans but the results have not reached the consensus of the local people. This is an issue that 
necessitates to be seriously considered because in the process of implementing land use planning in Vietnam the planners and authorities rely heavily on factors such as suitability with phisycal conditions, ensuring economic benefits, security - defense purposes, environment - sustainable development and other social goals just as income, employment... (MONRE, 2017) with little or without care for the attitude of people whose land will be acquired or converted. This could be a theoretical gap in land use planning that needs to be studied more.

Thai Nguyen City is a class - 1 urban area belonging to the province, the urban center which has the largest size and fastest growth economy, the fastest rate of urbanization and industrialization of Thai Nguyen province. In 2018, Thai Nguyen City's economic growth rate reached 16\%, attracted 27 investment projects with a capital of 37 trillion VND (Thai Nguyen city portal, 2019). Along with that growth, the demand for land funds for development projects is increasing.

While the development space in the central area has almost been exhausted, the area west of the city, including communes and wards: Phuc Xuan, Phuc Triu, Tan Cuong, Thinh Duc, Thinh Dan and Quyet Thang, has a relatively large land area for development. Practice shows that land acquisition and clearance in Thai Nguyen city have also faced difficulties when investors and local authorities do not reach consensus with the local people (Bac Son road project - from 1994 to 2020, Viet Bac road project (20 years), Thai Nguyen University Southern residential area project from 2007 until now still has problems ...).

In an effort to find solutions to help managers, planners have more bases to choose more suitable planning spaces. The author used questionnaires designed on five point likert scale to measure the attitudes of communities living in the western area of Thai Nguyen city if their land was acquired in the future. Survey results are analyzed and evaluated at three levels (very positive, positive and less positive), then digitized data and analyzed by GIS to determine the spatial of resident's attitudes.

\section{An overview}

\subsection{Researching about community's attitude toward land acquisiton}

Over the past years, researching the attitude of residential communities towards land acquisition and resettlement has been a problem which attracted the attention of many organizations and scientists. The results of these studies are considered as an important practical basis to support, supplement and complete the compensation and support policy upon land acquisition. These works exploited a variety of research methods and subjects with the aim of determining the concerns of the community when their land is acquired, include: the socio-economic impacts, the causes and solutions to the resolution of conflicts between stakeholders. In 1968, Bredo et al. (1968) used questionnaires to survey the attitudes of farmers living in hamlets (villages) and landowners (landlords) in rural southern Vietnam, serving land reform under the Republic of Vietnam regime. Meanwhile, some authors use the "sustainable livelihood theoretical framework" (Chuong \& Hoanh, 2010; An, 2012; Thuan et al., 2018)..., multiactor analytical framework (Consulting \& Gillespie, 2014), exploratory factor analysis method (EFA), regression analysis (single or multivariable) (Gallagher et al., 2008; Thuan et al., 2018), group analysis theory, fractional logit model (FLM) (Tuyen et al., 2014) combined with questionnaire, in-depth interview (Gallagher et al., 2008; (Chuong \& Hoanh, 2010; Thu Hang, 2017; An, 2012; Tuyen et al., 2014; Thao, 2015)..., focus group discussion (Thao, 2015; Maharjan, 2017), collective consultation (Khuy et al., 2014)... to assess community attitudes. Another problem that these studies have shown is the sampling methods. Following this, the most common method is sampling random technique that all people living in area where land acquisition take place get the same a chance to be sample of research (Bredo et al., 1968), (An, 2012; Hien, 2013; Chinh et al., 2013; Maharjan, 2017)... Besides, there are other sampling methods such as preliminary survey (Thao, 2015), calculated from statistics (Chuong \& Hoanh, 2010; Tuyen et al., 2014), using a snowball sampling model (Thu Hang, 2017) or according to the spatial extent affected by land acquisition (direction, population density ...) (Gallagher et al., 2008)... Regarding the sample size, there are also many methods used to prove the reliability of the surveys: investigating all related objects (Chinh et al., 2013), applying the theory of probability (Yamane's formula (Canh et al., 2015; Huong et al., 2018), Habing's formula (Thuan et al., 2018)...).

The results of these studies point to the main concerns of resident whose land is acquired regarding the following issues: land rental quota, compensation method, land value calculation method, property rights land (Bredo et al., 1968), living environment, employment, income, public services, well-informed (Thuan et al., 2018), information disclosure (An, 2012), vocational training, job creation for people post-acquisition (Thuy, 2017), adequate compensation, dialogues with stakeholders (World Bank, 2016)...

Regarding the causes of conflicts and contradictions between people and stakeholders in the land acquisition process, the studies show that the compensation price for land acquisition is lower than the market price (Canh et al., 2015; Nguyen et al., 2015), the people do not want to change current life (Canh et al., 2015), the organization of collecting opinions is still formal (Canh et al., 2015) are the main causes. Sharing this point of view but Son \& Trang (2014) as well as the World Bank (2016) emphasized the lack of transparency of information (Son \& Trang, 2014). In which, the World Bank also pointed out one of the specific reasons is the lack of the process of mobilizing the people on the basis of mobilizing the participation of the community, social organizations and participation directly of those who suffer. The current implementation often leads to conflicts between the government and the people, the people whose land is acquired always consider themselves victims of State policies (World Bank, 2016).

In terms of solutions to reduce conflicts in land acquisition, Hien \& Hoc (2013) pay much attention to the community's customary elements in policy and regulation development when recovering land for resettlement. Meanwhile, in Sri Lanka, understanding community attitudes is a basis for choosing the method of compensation for land acquisition and resettlement (De Silva, 2014). Dao Trung Chinh et al also pointed out that one of the requests of local people when their land is acquired is to negotiate directly with the project owner and allowed to participate in proposing, amending and issuing thenkaimpl price bracket every 1-3 years (Chinh et al., 2013). Pham Thanh Que also agrees when this author thinks that it is necessary to diversify forms 
of propaganda, awareness raising, and people's consensus in compliance with the policy of land acquisition; compensation; assistance and resettlement; building detailed compensation plan, complete and public compensation plans for people to ensure effective land acquisition (Que, 2013).

In summary, an overview of the above studies shows that, for the issue of recovering compensation and resettlement upon land acquisition, the authors, agencies and organizations all have the same opinion on promoting the role of residential community in implementing the policy of resettlement and recovery.

\subsection{Researching applying GIS to assessment of community attitude}

GIS is a very popular tool in the field of land management in general, but it is mandatory to apply GIS in assessing community attitudes towards land acquisition and land use conversion has not received much research attention. Some studies mainly stopped at the establishment of spatial maps, research locations (Nguyen et al., 2019) or further forward are the application of GIS for participatory mapping (Corbett, 2009).

Meanwhile, in some other fields, the application of GIS in community attitude assessment has appeared relatively popular. In 2006, Inbakaran et al. applied GIS to map the attitude factor of community in the Victorian region (Australia) based on of the results of resident's attitudes survey toward future tourism development activities. In 2007, Raymond \& Brown used GIS to map the attitudes and perceptions of communities and visitors toward tourism development in Otways (Australia). The purpose of this study is to prove the hypothesis: community attitudes and perceptions vary from place to place in an area. This result is the fundamental difference in the spatial (geographic) approach compared to the traditional survey methods which only give general results for the whole area but does not show differences between specific locations in an area. Similarly, Yu et al. (2019), Huy \& Lien (2020) used the spatial analysis tool of GIS to determine the spatial distribution of community attitudes towards participating in development of green infrastructure (GI) in Shanghai (China) (Yu et al., 2019) or tourism development in Halong Bay (Vietnam) (Huy \& Lien, 2020). Both of these studies used the spatial interpolation method (Kriging or IDW) based on digitized the results of the sociological survey to create community attitude maps.

In the medical and wellness fields, the application of GIS to spatial interpolation has been applied to solve some specific problems. In 2012, Gewa et al. used the IDW method to interpolate factors of overweight, iodine salt supply in women by territory in Mali. Meanwhile, Pande et al. (2008) used the "nearest neighbor interpolation - NNI) method to construct cholera risk assessment maps in Benin on multiple territorial levels from the population and health census data.

All of the above-mentioned studies show the ability of effective application of GIS for the purpose of assessing community attitudes towards a specific development activities.

\section{Research methodogy}

\subsection{Assessment of comminity attitude}

Attitude is a human psychological phenomenon, reflecting the relationship of the individual with the effects of the surrounding environment, action orientation individual, thoughts, and emotions which is expressed through human perception, emotions and behavior (Nguyet, 2019). According to Tran Hiep and Do Long, what a person feels, thinks, and imagines inside the human mind will determine the behavior shown outside of each person that means we will know the individual's behavior if we know his or her attitude. Therefore, in order to change individual's behavior, we must change the attitude of that individual (Hiep \& Long, 1991).

To measure attitudes, many scientists used questionare (closed questionnaire) that was designed with the five-point Likert scale (Raymond \& Brown, 2007; Dharmawardhana, 2017; Yu et al., 2019; Huy \& Lien, 2020),... to quantify the attitude (thinking) of the respondents about the research problem. In essence, the positive or negative attitude of the people towards a certain activity (work, project) (including the necessary activity of the local community) reflects their perceptions of benefits received or damages if any are economic, social, environmental and quality of life (refer to Gallagher et al., 2008).

In the framework of the article, the authors have conducted a survey on community attitudes on 8 indicators: 1 . The level of willingness to receive information about land acquisition; 2. Level of willingness to accept when land is acquired 3. Expected level of income after land acquisition; 4. Expected level of employment after land acquisition; 5. Level of anxiety (skepticism) about the habitat problem; 6 . The level of anxiety about social evils; 7 . The expected level of facilities to be benefited after land acquisition; 8. Level of opposition to land acquisition. Each indicator is measured by 1 question with 5 different assessment levels. With the community consensus survey question, the score scale will be calculated as follows: totally agree - 5 points, agree - 4 points, don't know - 3 points, disagree - 2 points and totally disagree opinion - 1 point. For question of objection or skepticism, the score is calculated opposite: strongly agree - 1 point, agree -2 points, do not know - 3 points, disagree - 4 points and completely Disagree - 5 points. The attitude level for each indicator of the samples by the communal administrative unit, gender or age ... is the average value of the attitude level (points) of all samples for each standard. Accordingly, the the higher the average score, the more positive the attitude, and vice versa.

Survey results for each criterion are used as input data for the integrated rating scale to draw conclusions about the level of positive or negative attitude of the community towards land acquisition. The integrated rating scale is built based on the weight of each criterion according to the following formula:

$$
\mathrm{a}_{\mathrm{n}}=\frac{\sum_{\mathrm{i}=1}^{8} \mathrm{n}_{\mathrm{i}} \mathrm{w}_{\mathrm{i}}}{8}
$$

Where an is the score for assessing the attitudes of the nth survey sample; ni is the score representing the attitude of the nth 
sample towards indicator $\mathrm{i}$; Wi is the weight of indicator i.

The weight of each criterion is determined by the method of Analytic Hierarchy Process (AHP). To obtain the weighting matrix (Table 1), we consulted 5 experts in the fields of psychology research, land studies, state management of land, real estate and business executive.

Table 1. The matrix determines the weights of the evaluation criteria for community attitudes according to the method of hierarchical analysis process (AHP)

\begin{tabular}{cccccccccc}
\hline Criteria & I & II & III & IV & V & VI & VII & VIII & Weight \\
\hline I & 1 & $1 / 5$ & $1 / 3$ & $1 / 3$ & 1 & 1 & $1 / 9$ & $1 / 3$ & $\mathbf{0 , 0 3 4 2}$ \\
II & 5 & 1 & 3 & 3 & 7 & 7 & $1 / 3$ & 5 & $\mathbf{0 , 2 2 9 2}$ \\
III & 3 & $1 / 3$ & 1 & 1 & 3 & 3 & $1 / 5$ & 3 & $\mathbf{0 , 1 0 2 9}$ \\
IV & 3 & $1 / 3$ & 1 & 1 & 3 & 3 & $1 / 5$ & 3 & $\mathbf{0 , 1 0 2 9}$ \\
V & 1 & $1 / 7$ & $1 / 3$ & $1 / 3$ & 1 & 1 & $1 / 9$ & $1 / 3$ & $\mathbf{0 , 0 3 2 9}$ \\
VI & 1 & $1 / 7$ & $1 / 3$ & $1 / 3$ & 1 & 1 & $1 / 9$ & $\mathbf{0 , 0 3 2 9}$ \\
VII & 9 & 3 & 5 & 5 & 9 & 9 & 1 & $\mathbf{0 , 3 9 3 9}$ \\
VIII & 3 & $1 / 5$ & $1 / 3$ & $1 / 3$ & 3 & 3 & $1 / 5$ & 1 & $\mathbf{0 , 0 7 1 2}$
\end{tabular}

( $I$ - willingness to receive information; II - willingness to accept land acquisition; III - expected level of income after land acquisition; IV. Expected level of employment after land acquisition; V-Level of environmental concern; VI-Level of anxiety about social evils; VII- level of opposition to land acquisition; VIII - expected level of facilities to beneficiaries after land acquisition)

On determining the sample size of the article survey using Yamane Taro's theory of statistical probability (Yamane, 1973) to calculate the sample size:

$$
\mathrm{n}=\frac{\mathrm{N}}{1+\mathrm{N}\left(\mathrm{e}^{2}\right)}
$$

where $\mathrm{n}=$ sample size, $\mathrm{N}=$ population, $\mathrm{e}=$ error tolerance (in this report is $5 \%$ ).

The average population of the research area is 71.428 people in 2017 that came from statistics of Thai Nguyen city People's Committee. Therefore, the appropriate number of completes will be 400 .

Sampling methods: this article used random sampling to select respondents for this survey.

\subsection{Spatial interpolation}

This is a very popular method in geography, cartography, environmental science and some other natural sciences. In essence, spatial interpolation is generally a process of estimating the value of areas (sites) not surveyed based on a system of known valid points (Wu \& Hung, 2016). There are two basic assumptions that make up space interpolation. The first hypothesis is spatial autocorrelation, as Tobler explains, "everything is related to everything else, but near things are more related than distant things" (Tobler, 1970). The second assumption is that the change in value takes place softly and continuously over space. In the field of social sciences, especially the issue of interpolation of attitudes of population communities has not been studied much. However, there are many studies that have demonstrated a great relationship between perceptions and demographic characteristics (living conditions, education, income, occupation ...) (Cunningham, 2007; Jha \& Ye, 2016)... Therefore, people living in an area where socio-economic conditions are similar can share the same perception of the fundamental issues affecting their individual and families's life. This is an important basis to hypothesize about the possibility of using spatial interpolation algorithms for community attitudes in a particular geographic area.

Currently, there are many spatial interpolation methods associated with specific algorithms: Spline algorithm, distance inverse algorithm (IDW), Kriging algorithm, Nearest Neighbor Interpolation (NNI)... The IDW method (algorithm) determines the value of the unknown points by using a combination of linear weights of a set of (known) sample points. Weight is a function of the inverse distance from the known point to the estimated point. Thus, the farther the points are from the point to be calculated, the less affect the computed value, the less weight will be reduced (Naoum \& Tsanis, 2004). The formula for interpolating value at an unknown point on the basis of known values around it is as follows (Yen et al., 2019):

$$
\mathrm{Z}=\frac{\sum_{\mathrm{i}=1}^{\mathrm{n}} \mathrm{Z}_{\mathrm{i}} \times \frac{1}{\mathrm{~d}^{\mathrm{k}}}}{\sum_{\mathrm{i}=1}^{\mathrm{n}} \frac{1}{\mathrm{~d}^{\mathrm{k}}}}
$$

Where $\mathrm{Z}$ is the value to be calculated; $\mathrm{i}$ are data points with known values; $\mathrm{n}$ is the number of points known; $\mathrm{Zi}$ is the value of the ith point; $d$ is the distance from the point to be taken into account at point $\mathrm{i}$; $\mathrm{k}$ is constant IDW (the higher $\mathrm{k}$ is the influence of the distant points is lower, normally $\mathrm{k}=2$ ).

Today, the GIS software (Arcgis, Mapinfo, Arcview, Qgis ...) have integrated spatial analysis tools with many algorithm such as IDW, NNI, Kriging, Spline... The analysis is done completely automatically. Input data are points, output can be surfaces representing continuously changing values.

The result of the spatial analysis is a continuous surface whose values are between 1 and 5. However, for convenience of evaluation these values will be classified into a three-order scale (Table 2) in community attitude assessment map.

Table 2. Integrated assessment scale

\begin{tabular}{cc}
\hline Degree of Attitude & $\mathbf{a}_{\mathbf{n}}$ \\
\hline Strongly Positive & $>3,5$
\end{tabular}




$\begin{array}{lc}\text { Positive } & 2,5-3,5 \\ \text { Nagative } & <2,5\end{array}$

\subsection{Community attitudes mapping}

The construction of maps is an important task to show the spatial distribution of community attitudes. In the article, the map system includes maps for assessment of community attitudes in the study area and component attitude maps (map of willingness to accept when land is acquired; map of expected post-acquisition employment; map of expected earnings after land acquisition; map of the expectation of utilities to be benefited after land acquisition; map of anxiety level (nostalgia suspicion) environmental and social issues; map of opposition to land acquisition).

The component maps were created based on the sociological survey data on population attitudes. Responses were coded in terms of scores (1-5) - which correspond to different attitudes. Each sample is physically located in the field, stored by a pair of coordinates $(\mathrm{x}, \mathrm{y})$ and a table of attribute data. Spatial interpolation of the attitude levels was performed under the support of the IDW tool in Arcgis.

The community attitude assessment map was created on the basis of overlaying component maps with the help of raster culculator tool (Arcgis). In which the relationship between the layers of the component map is established based on the weight of each factor (determined in Table 1).

\section{Materials Research}

\subsection{Secondary data}

Sources of information and data on socio-economic, current land use ... were collected from state management agencies in the city, inculuded:

- Report on the socio-economic situation of Thai Nguyen city in 2015, 2016, 2017, 2018 of Thai Nguyen City Statistical

Office.

- Map of Thai Nguyen city land use status in 2014, scale 1: 25,000 of the Center for Land Use Right Registration, Thai

Nguyen Department of Natural Resources and Environment;

- Topographic map of Thai Nguyen city area, scale 1: 50,000 of the Ministry of Natural Resources and Environment (archived at the Department of Natural Resources and Environment of Thai Nguyen province);

- Socio-economic report submitted to Thai Nguyen City Party Congress 2016.

\subsection{Primary data}

The data on residential community attitudes was surveyed by participants during the period 9/2018 to 4/2019 with 400 samples. General information on demographics of the sample is shown in Table 3:

Table 1. The demographic profile of the respondents

\begin{tabular}{|c|c|c|c|c|c|c|c|c|}
\hline & \multirow{2}{*}{ Criterion } & \multicolumn{7}{|c|}{ Commune } \\
\hline & & $\begin{array}{l}\text { Phuc } \\
\text { Triu }\end{array}$ & $\begin{array}{l}\text { Phuc } \\
\text { Xuan }\end{array}$ & $\begin{array}{l}\text { Quyet } \\
\text { Thang }\end{array}$ & $\begin{array}{c}\text { Tan } \\
\text { Cuong }\end{array}$ & $\begin{array}{c}\text { Tan } \\
\text { Thinh }\end{array}$ & $\begin{array}{l}\text { Thinh } \\
\text { Dan }\end{array}$ & $\begin{array}{l}\text { Thinh } \\
\text { Duc }\end{array}$ \\
\hline \multirow[t]{2}{*}{ Gender } & Male & 54 & 30 & 29 & 24 & 11 & 9 & 46 \\
\hline & Female & 34 & 34 & 22 & 12 & 29 & 27 & 39 \\
\hline \multirow[t]{4}{*}{ Age } & $<18$ & 0 & 2 & 0 & 0 & 0 & 0 & 0 \\
\hline & $18-35$ & 32 & 24 & 12 & 6 & 18 & 16 & 12 \\
\hline & $35-60$ & 33 & 18 & 15 & 13 & 13 & 11 & 44 \\
\hline & $>60$ & 23 & 20 & 24 & 17 & 9 & 9 & 29 \\
\hline \multirow{4}{*}{$\begin{array}{l}\text { Length } \\
\text { Residence }\end{array}$} & $<5$ & 8 & 7 & 8 & 0 & 0 & 1 & 1 \\
\hline & $5-15$ & 16 & 9 & 11 & 2 & 12 & 11 & 2 \\
\hline & $15-25$ & 12 & 7 & 5 & 2 & 5 & 3 & 24 \\
\hline & $>25$ & 52 & 41 & 27 & 32 & 23 & 21 & 58 \\
\hline \multirow[t]{5}{*}{ Education } & Primary & 4 & 14 & 7 & 1 & 1 & 0 & 14 \\
\hline & Junior high school & 31 & 18 & 14 & 5 & 4 & 3 & 39 \\
\hline & High school & 26 & 18 & 13 & 21 & 4 & 3 & 15 \\
\hline & Vocational & 14 & 8 & 9 & 4 & 13 & $\begin{array}{c}13 \\
\text { www.jirp.org }\end{array}$ & 7 \\
\hline & Higher & 7 & 2 & 6 & 5 & 14 & 14 & 10 \\
\hline
\end{tabular}




\begin{tabular}{|c|c|c|c|c|c|c|c|c|}
\hline & Postgraduate & 6 & 4 & 2 & 0 & 4 & 3 & 0 \\
\hline \multirow[t]{8}{*}{ Occupation } & Agricultural laborers & 20 & 16 & 12 & 7 & 1 & 0 & 44 \\
\hline & Officer, soldier and police & 14 & 5 & 8 & 6 & 14 & 13 & 17 \\
\hline & Private services & 6 & 0 & 4 & 2 & 5 & 3 & 5 \\
\hline & Worker & 18 & 13 & 10 & 8 & 12 & 11 & 13 \\
\hline & Craft worker & 4 & 1 & 2 & 3 & 0 & 0 & 1 \\
\hline & Retied group & 9 & 2 & 5 & 5 & 8 & 9 & 3 \\
\hline & \multirow{2}{*}{$\begin{array}{l}\text { Arts and sports } \\
\text { Other }\end{array}$} & 0 & 1 & 2 & 0 & 0 & 0 & 0 \\
\hline & & 17 & 26 & 8 & 5 & 0 & 0 & 2 \\
\hline \multirow{6}{*}{$\begin{array}{l}\text { Household } \\
\text { size } \\
\text { (person) }\end{array}$} & 1 & 3 & 0 & 0 & 1 & 0 & 0 & 0 \\
\hline & 2 & 0 & 8 & 2 & 5 & 2 & 2 & 4 \\
\hline & 3 & 18 & 14 & 5 & 9 & 11 & 8 & 4 \\
\hline & 4 & 33 & 18 & 14 & 11 & 26 & 24 & 49 \\
\hline & 5 & 7 & 13 & 8 & 1 & 1 & 2 & 4 \\
\hline & $>5$ & 27 & 11 & 22 & 9 & 0 & 0 & 24 \\
\hline \multirow{9}{*}{$\begin{array}{l}\text { Household } \\
\text { income } \\
\text { (Millions } \\
\text { VND per } \\
\text { month) }\end{array}$} & $<5$ & 3 & 6 & 2 & 2 & 1 & 0 & 4 \\
\hline & $5-10$ & 33 & 18 & 12 & 4 & 2 & 2 & 55 \\
\hline & $10-15$ & 30 & 22 & 15 & 14 & 36 & 32 & 16 \\
\hline & $15-20$ & 2 & 1 & 17 & 5 & 1 & 2 & 3 \\
\hline & $20-25$ & 3 & 4 & 4 & 11 & 0 & 0 & 4 \\
\hline & $25-30$ & 14 & 11 & 1 & 0 & 0 & 0 & 3 \\
\hline & $30-35$ & 0 & 2 & 0 & 0 & 0 & 0 & 0 \\
\hline & $35-40$ & 0 & 0 & 0 & 0 & 0 & 0 & 0 \\
\hline & $>40$ & 3 & 0 & 0 & 0 & 0 & 0 & 0 \\
\hline
\end{tabular}

\section{Research area}

Thai Nguyen City is the economic, political, cultural, social, security and defense center of Thai Nguyen province, located $80 \mathrm{~km}$ far north of Hanoi capital. The study area includes communes located in the western part of Thai Nguyen City: Tan Cuong, Phuc Triu, Thinh Duc, Quyet Thang, Phuc Xuan, Thinh Dan and Tan Thinh which are connected to the city center by provincial roads 261 and 267. The total natural area of Thai Nguyen city is about $91.17 \mathrm{~km} 2$ and population approximately 71,428 people, average density of population is over 783 people / km2 (Statistic Office of Thai Nguyen City, 2018). The main economic activities of the residents in the region are agriculture, the spiritual and material life of the people is lower than that of the city center.

Regarding the current land use, according to statistics of the Statistical Office of the city, the study area has a total natural area of 9,117 ha, accounting for $40.9 \%$ of the total natural area of the city, of which:

So, basically the study area has a quite large natural land area, agricultural land still accounts for a high proportion, so the prospect of changing the use purpose is still relatively large.

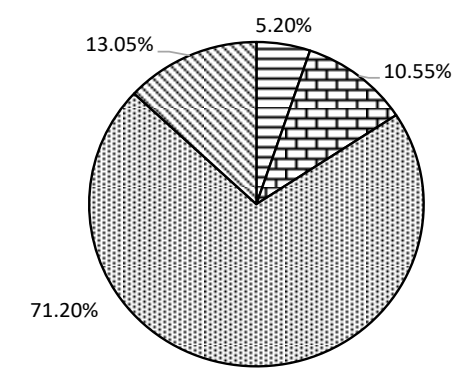

$\square$ Residental land

$\boxplus$ Specialized land

国 Agricultural land

Other land

Figure 1. Land use structure in the western part of Thai Nguyen city (2017) 


\section{Result and Discussion}

\subsection{Attitude levels according to each criterion}

- The level of willingness to receive information about land acquisition

Analysis results show that $29 \%$ of respondents do not believe that their land will be acquired in the future, $15.5 \%$ do not believe their land will be acquired, 5.8\% said that they don't know. On the other hand, 28.8\% of respondents believe that their land will inevitably be acquired in the future, $21 \%$ believe that their land could be acquired. In terms of the spatial attitudes, people live in wards and communes where bordering the city center have a higher level of willingness to receive information than people living in remote communes (figure 2).

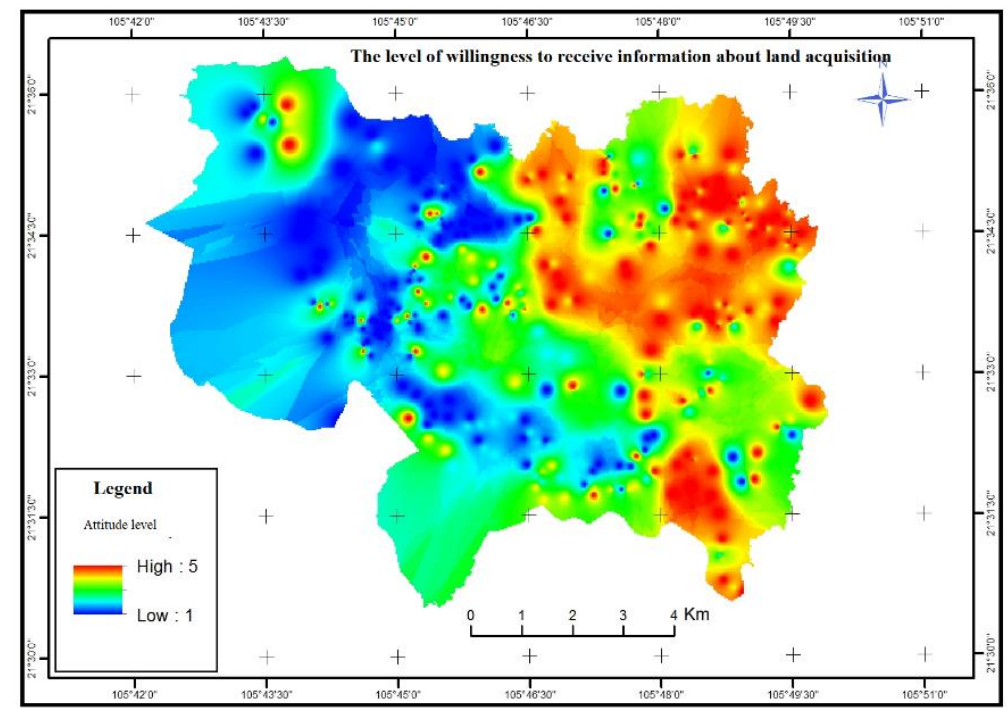

Figure 2. The level of willingness to receive information

Regarding the relationship between the attitudes and demographic characteristics of the sample, the analysis shows that men have lower willingness to receive information than women (2.7 and 3.41); those aged 35-60 had the highest readiness level (3.2), followed by those aged 18-35 (2.96) and those aged 60 and over (2.99) while the group under 18 years old was the lowest (1.0); The group of people with higher education level is more willing to receive information than the group with lower level of education. High-income earners show an unwillingness to receive information, while low-income earners show more positive attitudes.

- Level of willingness to accept when land is acquired

The analysis results show that $29.5 \%$ of respondents absolutely do not believe that their life after land acquisition will be better than current, $18.5 \%$ at unbelief level, $3.0 \%$ answer them do not know. On the other side, $38.5 \%$ of respondents believe that their life will be better than nowadays after the land is acquired, $10.5 \%$ completely believe that their life will be better after land acquisition.

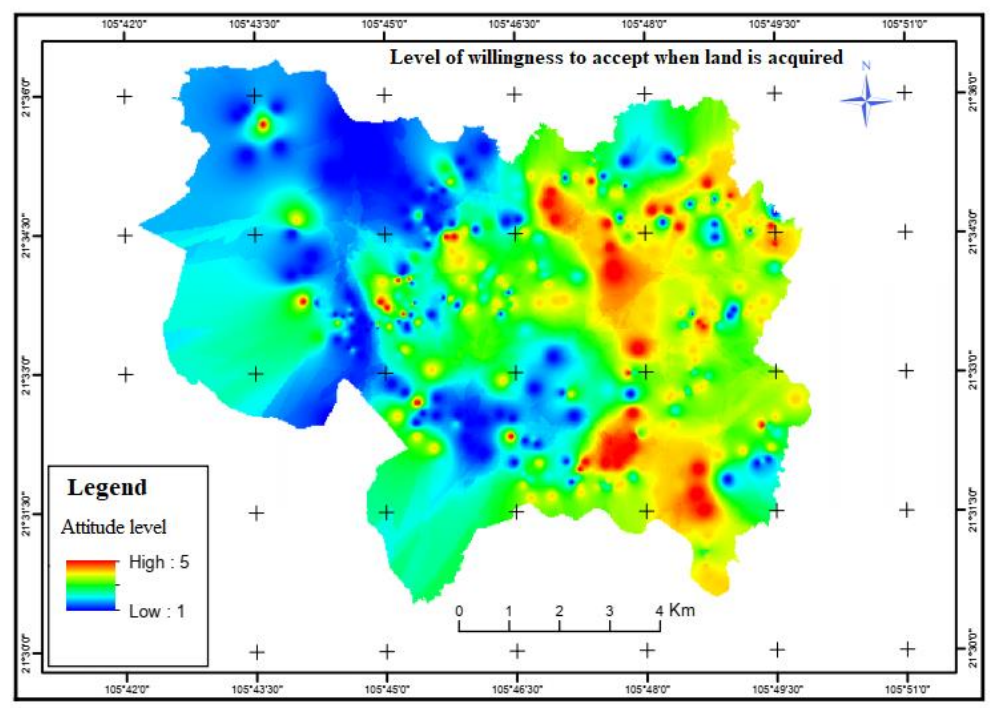

Figure 3. Level of willingness to accept when land is acquired 
In terms of spatial relationship between attitudes, people in wards and communes bordering the city center have a higher level of willingness to accept than those living in remote communes (figure 3). Except for Thinh Duc commune, although it is a commune far from the center, this index is the highest (3.66), possibly because many people in the commune have been compensated a large amount of money from the project "An Lac Vien"so the level of optimism is very high.

Regarding the relationship between the attitudes and demographic characteristics of the sample, the analysis shows that men have lower willingness to accept than women (2.7 and 2.94); The expression of this attitude in age groups is quite similar, not much difference; The group of people with higher levels of education (high school graduate or higher) have a higher willingness to accept than the group with lower levels. People with high incomes (over 30 million VND/month) show less positive attitudes compared to low income earners.

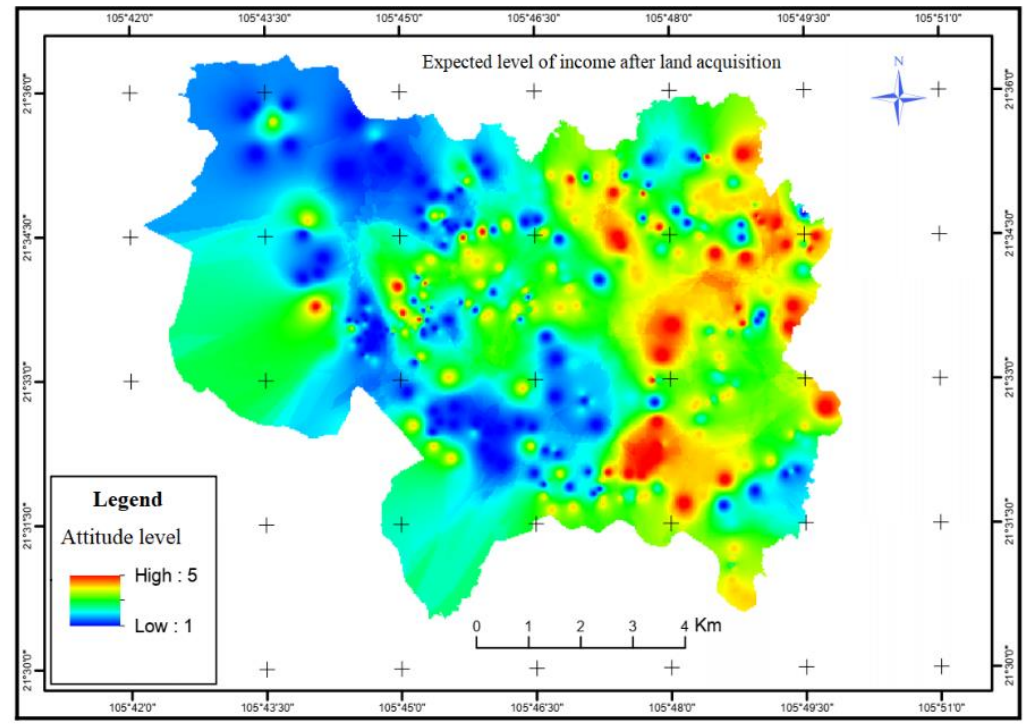

Figure 4. Expected level of income after land acquisition

- Expected level of income after land acquisition

The analysis shows that $29.3 \%$ of respondents think that their income will definitely decrease after their land is acquired, $20.8 \%$ think that their income could be reduced. When the land was acquired, $2.8 \%$ were unsure of the answer. On the other side, $37.0 \%$ of respondents fully trust and $10.3 \%$ have confidence that their income will increase compared to the present when the land is acquired.

In terms of spatial relationship between attitudes, people in wards and communes bordering the city center have a higher level of expectation than those living in remote communes (Figure 4).

Regarding the relationship between the attitudes and demographic characteristics of the sample, the analysis shows that: men have lower income expectations than women (2.61 and 2.96 ); The level of income expectation between age groups is quite similar; The group of people with higher education has a higher level of income expectations than those with lower education. Whereas high-income earners exhibited lower levels of expectations compared to low-income earners.

- Expected level of employment after land acquisition

The analysis results show that $39.1 \%$ of respondents expressed a negative attitude about employment opportunities after land acquisition. In which, $12.8 \%$ showed a very negative attitude, $26.3 \%$ expressed a negative attitude. On the other hand, the number of people showing positive attitudes about job opportunities accounts for $57.3 \%$, of which $25.3 \%$ have the attitude of completely trusting job opportunities, $32 \%$ have confidence about job opportunities. The remaining $3.8 \%$ of people are unsure of the answer.

In terms of the spatial relationship between attitudes, people in wards and communes bordering the city center have a higher level of willingness to receive information than those living in remote communes (figure 5).

Regarding the relationship between the attitudes and demographic characteristics of the survey samples, the analysis results show that: with this indicator, men and women have a fairly balanced attitude towards employment expectations (3.26 and 3.36); The level of job expectation is also quite good among age groups, most notably the group under 18 years old showing absolute confidence (5.0); The group of people with higher education level shows more positive job expectation (from 3.59 to 4.42) and the group of people with lower education (ranges from 2.37 to 3.31). Meanwhile, high-income earners show lower levels of expectation compared to low-income earners, specifically: those (in the household) with incomes from 25 million per month have a Attitudes ranged from (1.33 - 2.21), those with incomes below 25 million / month showed attitudes in the range of $(3.08-3.56)$. 


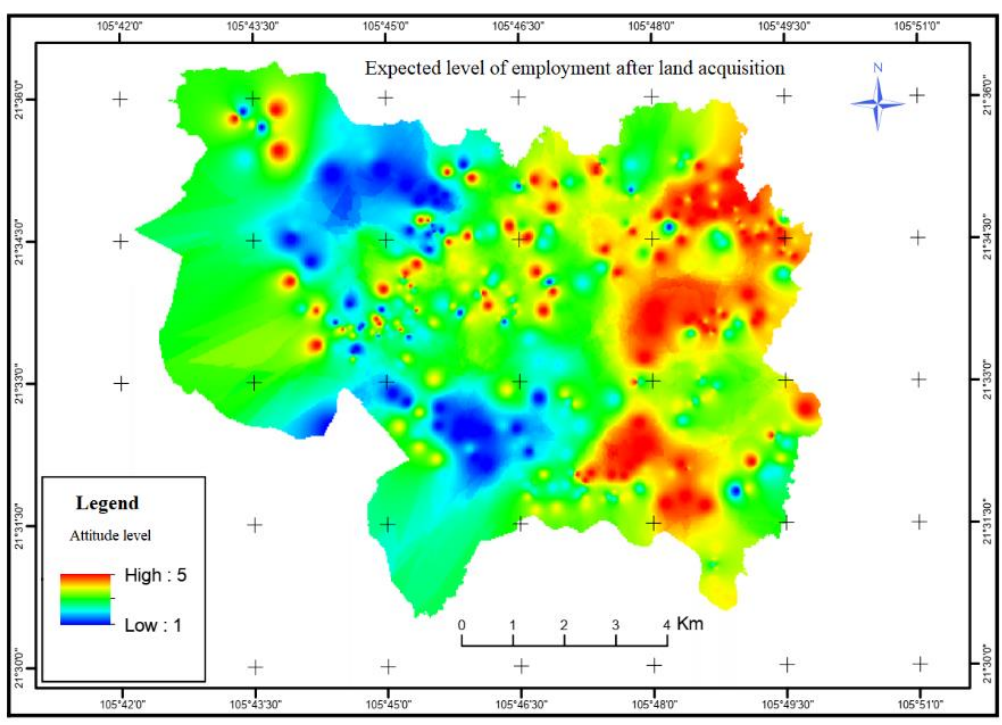

Figure 5. Expected level of employment

\section{- Level of anxiety (skepticism) of environment}

The analysis results show that $85 \%$ of respondents show negative attitudes about the living environment after land acquisition. In which, $57 \%$ showed a very negative attitude, $28 \%$ expressed a negative attitude. On the other hand, only $15 \%$ of people show a positive attitude about their living environment, of which $7 \%$ completely do not believe and $8 \%$ do not believe that their living environment will deteriorate after the land is acquired.

In terms of space, for this criterion, most of the respondents showed a negative attitude, with the average only reaching (1.8). In which, Thinh Duc commune has the most positive attitude (2.87), Tan Cuong is the commune with the most negative attitude (1.22) (figure 6).

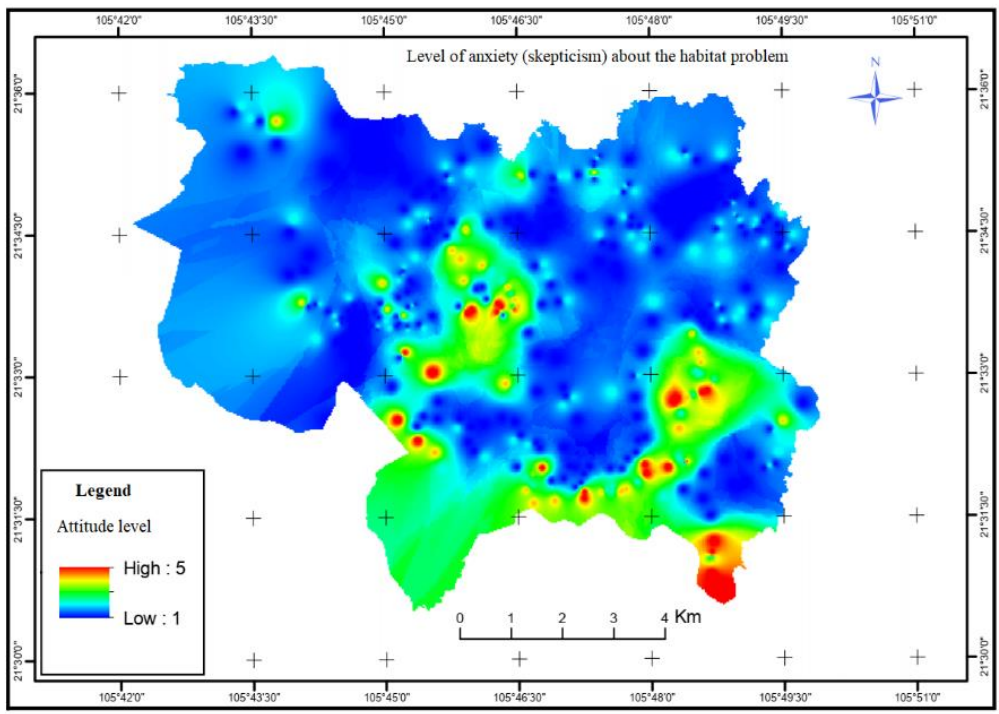

Figure 6. Level of anxiety (skepticism) of environment

Regarding the relationship between the attitudes and demographic characteristics of the survey samples, the analysis results show that: with this indicator, men and women have a fairly balanced attitude of anxiety about the problem habitat problem (1.75 and 1.85); The level of environmental anxiety among age groups is also very balanced and all show a negative attitude (from 1.52 to 2.07); The whole group of people with high and low education has very negative attitude about the environment after land acquisition (from 1.0 to 2.64). In addition, when comparing attitudes of high-income earners and low-income people, there are similarities $(1.08-2.74)$.

- The level of anxiety about social evils

The analysis results show that $78 \%$ of respondents show negative attitudes about social evils after land acquisition. In which, $49.5 \%$ showed a very negative attitude, $28.5 \%$ showed a negative attitude. On the other hand, the number of people showing positive attitudes about social evils is only $19.3 \%$, of which $6.8 \%$ completely do not believe and $12.5 \%$ do not believe that social evils will increase after the land is acquired. There are $2.8 \%$ of respondents do not express any opinion on this issue.

In terms of space, anxiety about the increase in social evils after land acquisition occurs in all localities, the majority of respondents show negative attitudes, with an average of only reaching (1.99). In which Thinh Duc commun positive attitude (2.91), Thinh Dan is the commune with the most negative attitude (1.0) (figure 7). 


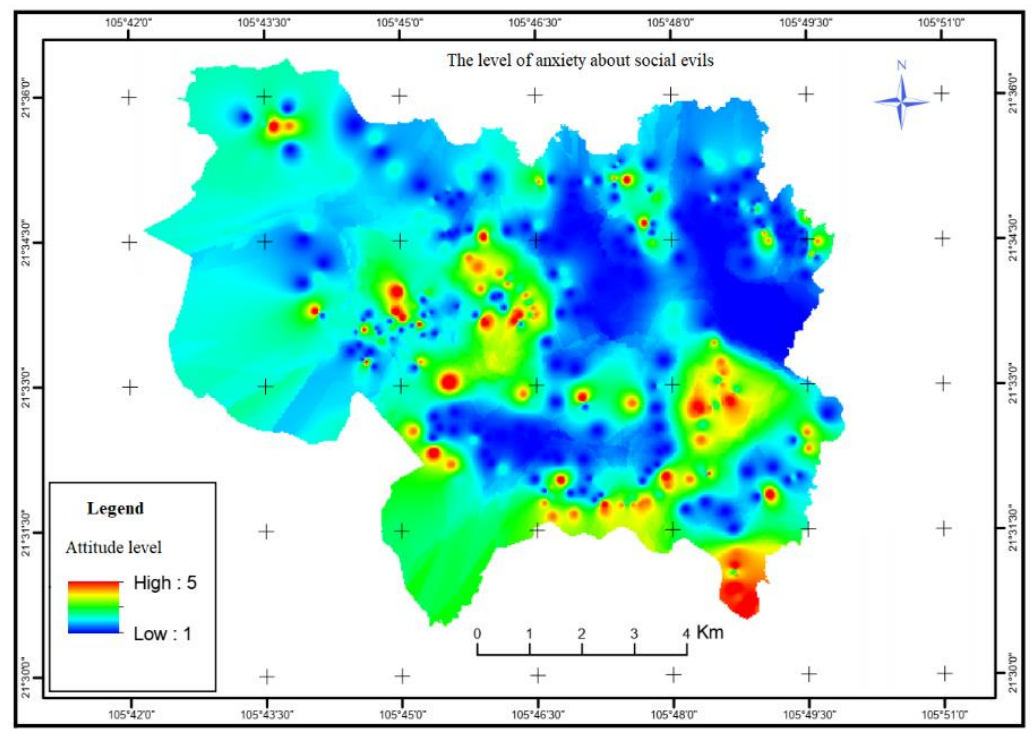

Figure 7. The level of anxiety about social evils

Regarding the relationship between the attitudes and demographic characteristics of the sample, the analysis showed that: with this indicator, men showed more positive attitudes than women (2.05 and 1.92); The level of environmental anxiety among age groups is also very balanced and all show negative attitudes (from 1.79 to 2.17); The whole group of people with high and low education levels have very negative attitudes about the environment after land acquisition (from 1.26 to 2.84). In addition, when comparing the attitudes of high-income earners and low-income earners, similarities are found (1.19 - 2.9).

\section{- Level of opposition to land acquisition}

The analysis results show that: $38.6 \%$ of the respondents expressed their opposition to the land acquisition. Of which, $29.3 \%$ expressed a completely opposed attitude, and 9.3\% expressed an objection. On the other side, 50.3\% expressed support for land acquisition if any, of which $21.8 \%$ fully supported and $28.5 \%$ expressed support. $11.3 \%$ of the respondents do not express an opinion on this matter. In terms of space, the level of opposition from the community is shown similarly to other indicators. Provinces near the city center had a more positive attitude than remote communes, with the exception of Thinh Duc commune (3.86) (figure 8).

Regarding the relationship between the attitudes and demographic characteristics of the survey samples, the analysis results show that men and women show a very balanced attitude (3.06 and 3.03); There is also a clear differentiation among age groups, with the most positive attitude in the age group 35-60 (3.45), and the group below 18 years old showing the most negative attitude (1.0). For the educational attainment criteria, the results showed that the group of people with high education showed a more positive attitude (college graduate -3.71 and postgraduate -4.53 ).

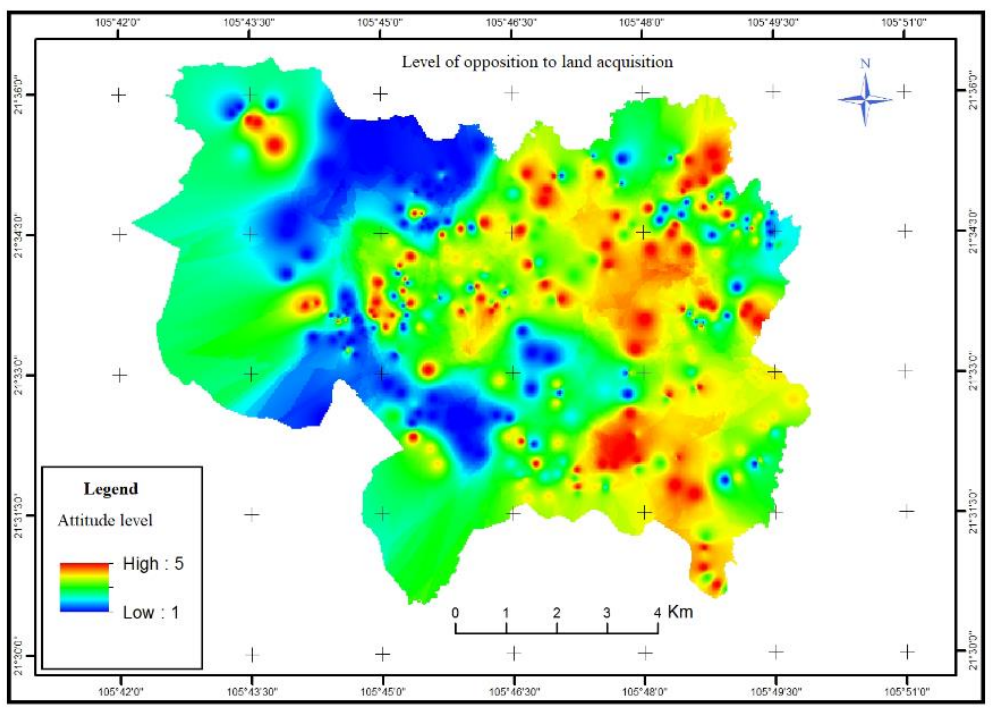

Figure 8. Level of opposition to land acquisition

\section{- The expected level of facilities to be benefited after land acquisition}

The analysis results show that: only $15.6 \%$ of respondents show a negative attitude towards utilities that will be benefited after land acquisition. In which, $6.8 \%$ showed a completely negative attitude, and $8.6 \%$ showed a negative attitude. On the opposite side, up to $72.0 \%$ of respondents believe that the benefits they enjoy will be better than the present, of ${ }^{w h i c h} 42 \%$ 
completely trust and $30 \%$ trust, $12.5 \%$ of respondents do not express any opinion on this matter.

In terms of spatial differentiation, in this indicator most of the respondents have a positive attitude about the facilities to be benefited and there is not much difference between communes and wards in the study area (figure 9).

Regarding the relationship between the attitudes and demographic characteristics of the survey samples, the analysis results show that men and women show a very balanced attitude (3.91 and 3.92); Attitude levels among age groups are also very similar (the age group 18-35 has the lowest confidence - 3.68, the age group over 60 shows the largest belief - 4.06). With regard to educational attainment, the results were similar when all groups had a high degree of confidence in the benefits to be enjoyed.

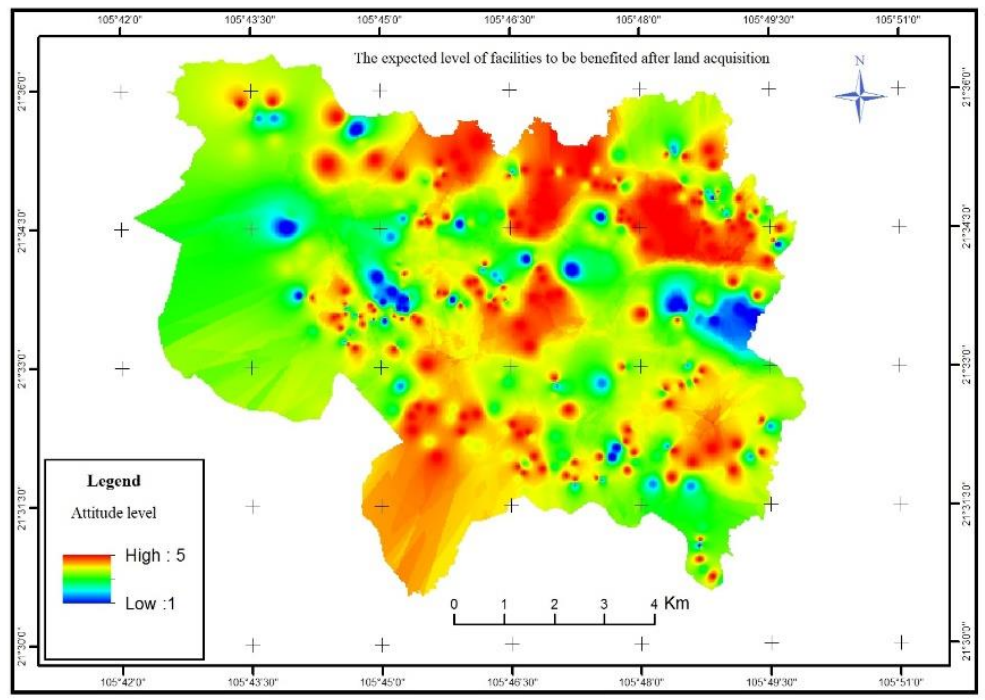

Figure 9. The expected level of facilities to be benefited

\subsection{Integrated assessment of local community attitudes}

Community attitudes are aggregated through the method of calculating the average score of component attitudes (with weights determined in table 1.1) and divided into 3 levels: less positive, positive and strongly positive (according to table 2). The analysis results show that $34.5 \%$ of respondents show a less positive attitude towards land acquisition, $21 \%$ have a positive attitude and $44.5 \%$ show a very positive attitude. In which, women have more positive attitudes than men, people in the age group $35-60$ have the most positive attitude. Those with a university or higher degree have the most positive attitudes. In terms of space, communities in Thinh Duc, Tan Thinh, and Thinh Dan communes have a more positive attitude.

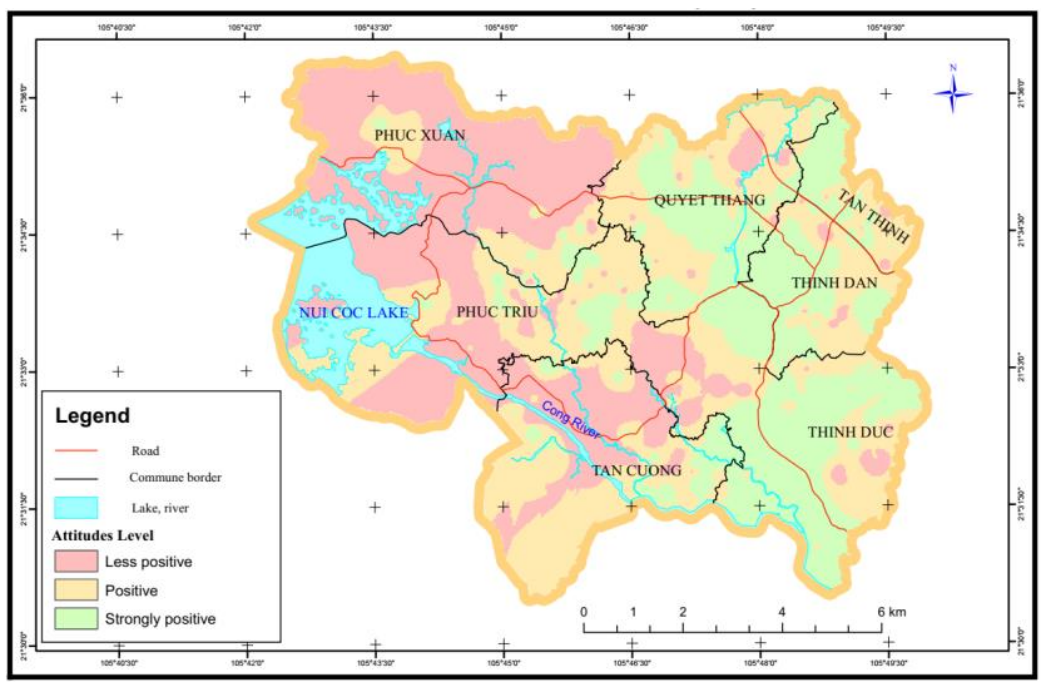

Figure 10. Map of integrated community attitudes

Calculation results from the map show that the area with very positive attitude is mainly distributed in Quyet Thang, Thinh Duc, Tan Thinh and Thinh Dan communes with an area of about 2,329 ha. Positive attitudes were mainly distributed in the east of Phuc Triu commune, the west and northeast of Quyet Thang commune, south of Tan Cuong commune, east of Thinh Duc commune with an area of about 3,376 ha. The rest is the area with less positive attitude, mainly distributed in Phuc Xuan, Phuc Triu, Tan Cuong communes with an area of about 3,339.5 ha. 


\section{Conclude}

The results of this research allow to make the following conclusions:

In the process of land use planning as well as implementing land acquisition for socio-economic development projects, national security and defense purpose, the authorities and project owners must consider the community's attitude to be very important factors should be seriously considered to ensure maximum efficiency.

People with high education, middle-aged and female people will have more active attitudes in site acquisition and clearance.

Meanwhile, people with high incomes or jobs directly dependent on land tend to oppose land acquisition.

Communities of Thinh Duc, Tan Thinh and Thinh Dan communes have more positive attitude towards land acquisition than other area belonging to the Thai Nguyen city. Therefore, in the coming time, these areas should be given priority to the conversion of land use purposes, to avoid conflicts and contradictions .

GIS is an effective support tool for spatial analysis of the resident's attitude towards land acquisition.

\section{References}

(MONRE), M. of N. R. \& E. (2017). Paper on orientation to land use planning in the Mekong Delta in association with sustainable socio-economic development https://cvdvn.files.wordpress.com/2017 /09/1-2-3-6_bao-cao-c491bscl-24_9-tcqldd.pdf

An, N. T. T. (2012). Evaluate the impact of land acquisition and site clearance on people's livelihoods at the project to build new urban areas in Hai An district, Hai Phong city (Vietnamese) [VNU University of Science]. https://repository.vnu.edu.vn/flowpaper/simple_document.php?subfolder= 54/20/21/\&doc=54202101057360839666555964997929975814\&bitsid=2e8218fe-bc1a-434d-aa16-78bbaad431ba\&uid=

Bredo, W., Shreve, R. O., \& Slawson, P. S. (1968). Land Reform in Vietnam (Volume 4, Part 1; Surveys and Analyses Related to Land Tenure Issues). https://books.google.com.vn/books?id=5eIkAQAAM AAJ\&printsec=frontcover\#v=onepage\&q\&f=false

Canh, T. T., Lai, T. N. C., \& Tuan, N. H. (2015). Evaluation of the conflict arising from the use of land resources in the process of urbanization at Da Nang City. Science \& Technology Development, 18(T6), 166-178. https://www.researchgate.net/publication/314152822_Danh_gia_xung_dot_phat_ sinh_trong_su_dung_tai_nguyen_dat_tu_qua_trinh_do_thi_hoa_tai_Thanh_pho_Da_Nang

Chinh, D. T., Vo, D. H., \& Tra, N. T. (2013). Assessment of Implementing the Land Acquisition, Compensation, Supports and Resettlement as Stipulated by Law (Vietnamese). J. Sci. \& Devel., 11(3), 328-336. http://www1.vnua.edu.vn/tapchi/Upload/2972013-Bai 8. 328-336.pdf

Chuong, H. Van, \& Hoanh, N. H. (2010). Influence of converting agricultural land into non- agricultural land on farmers' livelihoods in Hoi An city, Quang Nam province (Vietnamese). Hue University Journal of Science, 62A, 47-58. http://www.hueuni.edu.vn/portal/data/doc/tapchi/62A_5.pdf

Consulting, T., \& Gillespie, J. (2014). Public Land Disputes in Vietnam A Multi-Actor Analysis of Five Case Studies with an East Asian Comparative. https://asiafoundation.org/resources/pdfs/Publicland disputesreport.pdf

Corbett, J. (University of B. C. O. (2009). Good practices in participatory mapping. In International Fund for Agricultural Development (IFAD). International Fund for Agricultural Development. https://www.ifad.org/documents/38714170/39144386/PM_web.pdf/7c1eda69-8205-4c31-8912-3c25d6f90055

Cunningham, G. B. (2007). Perceptions as reality: The influence of actual and perceived demographic dissimilarity. Journal of Business and Psychology, 22(1), 79-89. https://doi.org/10.1007/s10869-007-9052-y

De Silva, S. H. U. (2014). A Study of Affected Households' Attitude towards the Mode of Compensation for Land Acquisition in Colombo-Kandy Alternative Highway Project. https://doi.org/10.31357/ fmscmst.2014.00351

Dharmawardhana, H. M. T. (2017). Attitude of Affected Households Towards the Mode of Compensation and Possible Issues Due To Land Acquisition for Expressway Projects in Sri Lanka [University of Moratuwa, Sri Lanka]. http://dl.lib.mrt.ac.lk/bitstream/handle/123/13394/Pre-text.pdf?sequence=2\& isAllowed $=\mathrm{y}$

Dung, V. (2013). The script of defendant Doan Van Vuon (Vietnamese). Vnexpress. https://vnexpress.net/ki-ch-ba-n-da-n-tra-n-cu-a-bi-ca-o-doa-n-van-vuon2606358.html

Gallagher, L., Ferreira, S., \& Convery, F. (2008). Host community attitudes towards solid waste landfill infrastructure: Comprehension before compensation. Journal of Environmental Planning and Management, 51(2), 233-257. https://doi.org/10.1080/09640560701864878

Gewa, C. A., Leslie, T. F., \& Pawloski, L. R. (2012). Geographic distribution and socio-economic determinants of women's nutritional status in Mali households. Public Health Nutrition, 16(9), 1575-1585. https://doi.org/10.1017/S136898001200451X

Hien, P. T. (2013). Compensation, support and resettlement - seen from the people whose land is acquired in Can Tho (Vietnamese). Journal of Legislative Studies (Vietnam National Assembly Office), 11(243), 45-52. http://lapphap.vn/Pages/tintuc/tinchitiet.aspx?tintucid=207129\#

Hien, P. T., \& Hoc, D. Van. (2013). The influence of traditional factors on people's psychology in land acquisition, compensation, assistance and resettlement. Can Tho University Journal of Science, 4, 40-48. https://www.academia.edu/35884302/Ảnh_hưởng_của_yếu_tố_tập_quán_truyền_thống_đến tâm_lý_người_dân_trong_thu_hồi_đất_bồi_thường_và_hỗ_trợ_tái_định_cư

Hiep, T., \& Long, D. (1991). Psychological handbook (Vietnamese). Social Sciences publishing house.

Huong, H. (2019, September 12). Complaints and denunciations focus mainly on land (Vietnamese). Quochoi.Vn. http://quochoi.vn/UserControls/Publishing/News/BinhLuan/pFormPrint.aspx?UrlList Process=/content/tintuc/Lists/News\&ItemID=41808

Huong, N. T. T., Huyen, P. T. T., Tra, N. T., \& Nam, P. P. (2018). Solutions to Complete the Land Acquisition for Development of Infrastructure And Urban Improvement in Nam Dinh City, Nam Dinh Province. Vietnam J. Agri. Sci, 16(8), 753-762. http://tapchi.vnua.edu.vn/wp-content/uploads /2019/02/tapchi-so-8.6.51.pdf

Huy, C. T., \& Lien, N. T. B. (2020). Applying Gis for Assessment of Residents Attitudes Toward Tourism in World Heritage Halong Bay, Vietnam. International Journal of Advanced Research and Publications, 4(3), 101-106. http://www.ijarp.org/online-papers-publishing/mar2020.html

Inbakaran, R. J., Jackson, M. S., \& Chhetri, P. (2006). Regional Tourism Attitude Maps : A spatial approach to the community attitudes towards tourism in regional Victoria , Australia. In Terry V. Liu (Ed.), Tourism Management: New Research (pp. 65-90). Nova Science Publishers.

Jha, S., \& Ye, C. (2016). The Impact of Demographic Variables on Perception of Importance and Continued Usage of Facebook in the US. Global Business Review, 17(1), 1-15. https://doi.org/ 10.1177/0972150915610666

Khuy, N. T., Bong, N. D., \& Tam, D. T. (2014). Community Consultation in Compensation Support and Resettlement when the State Recovers Land in Luong Son District, Hoa Binh Province (Vietnamese). J. Sci. \& Devel, 12(5), 727-733. http://www1.vnua.edu.vn/tapchi/Upload/2102014-tc so 5 13.pdf

Lua, T. (2016). "Hot" at the trial related to the Ecopark Van Giang project (Vietnamese). Tuoi Tre Online. https://tuoitre.vn/nong-tai-phien-xet-xu-lien-quanden-du-an-ecopark-van-giang-1115899.htm

Maharjan, K. (2017). Local Communities' Responses towards Land Dispossession in Nepal: Contradictions, Perception and Resistance. Journal of Land and Rural Studies, 5(1), 31-49. https://doi.org/10.1177/2321024916677598

Morris, S., \& Pandey, A. (2007). Towards reform of land acquisition framework in India. Economic and Political Weekly, 42(22), 2083-2090. https://doi.org/10.2307/4419665

Naoum, S., \& Tsanis, I. K. (2004). Ranking spatial interpolation techniques using a GIS-based DSS. Global Nest Journal, 6(1), 1-20. https://doi.org/10.30955/gnj.000224

Naoyuki Yoshino, Rasyad A. Parinduri, Y. O. (2019). Attitudes toward land acquisition in Indonesia. In Land Acquisition in Asia Towards irbş orstainable Policy Framework (pp. 57-79). Palgrave Macmillan, Singapore. https://doi.org/https://doi.org/10.1007/978-981-13-6455-6 
Nguyen, Q. P., Zoomers, A., \& van Westen, A. C. M. (2015). Compulsory land acquisition for urban expansion: A study of farmer 's protest in peri-urban Hue, Central Vietnam. Land Grabbing, Conflict and Agrarian-environmental Transformations: Perspectives from East and Southeast Asia, An International Academic Conference 5-6 June 2015, Chiang Mai University, Conference Paper No. 59, 59, 19. https://www.iss.nl/sites/corporate/files/CMCP_59Phuc_et_al.pdf

Nguyen, T. T., Hegedũs, G., \& Nguyen, T. L. (2019). Effect of Land Acquisition and Compensation on the Livelihoods of People in Quang Ninh District , Quang Binh Province: Labor and Income. Land, 8(91), 1-10. https://doi.org/doi:10.3390/land8060091

Nguyet, D. T. N. (2019). Theoretical research on some of the prisoners' attitudes towards the observance of the labor regime in the prison (Vietnamese). Vietnam Journal of Education, 53, 15-18, 5. https://tapchigiaoduc.moet.gov.vn/vi/magazine/download/\%3Fdownload\%3D1\%26catid\%3D377\%26id\% $3 \mathrm{D} 6738+\& \mathrm{~cd}=2 \& \mathrm{hl}=\mathrm{en} \& \mathrm{ct}=\mathrm{clnk} \& \mathrm{gl}=\mathrm{vn}$

Pande, S., Keyzer, M. A., Arouna, A., \& Sonneveld, B. G. J. S. (2008). Addressing diarrhea prevalence in the West African Middle Belt: Social and geographic dimensions in a case study for Benin. International Journal of Health Geographics, 7(17), 1-17. https://doi.org/10.1186/1476-072X-7-17

Que, P. T. (2013). Evaluation of site acquisition, compensation and support for site clearance when agricultural land is acquired to implement a number of projects in Thai Binh city (Vietnamese). College of Land Management and Rural Development. http://qldd.vnuf.edu.vn/documents/1465312/ 2808986/ĐÁNH GIÁ CÔNG TÁC THU HỒI\%2C BỒI THƯỜNG\%2C HỖ TRỢ GIẢI PHÓNG MẶT BẰNG KHI THU HỒI ĐÂT NÔNG NGHIẸP ĐỄ THỰC HIỆN MỘT SỖ DƯ ÁN TRÊN ĐỊA BÀN TP THÁI BÌNH.pdf

Raymond, C., \& Brown, G. (2007). A Spatial Method for Assessing Resident and Visitor Attitudes Towards Tourism Growth and Development. Journal of Sustainable Tourism, 15(5), 1-22. https://doi.org/10.2167/jost681.0

Son, P. X., \& Trang, V. H. (2014, June 23). Causes of land conflicts in Vietnam (Vietnamese). Political Theory Journal. http://lyluanchinhtri.vn/home/index.php/ thuc-tien/item/724-nguyen-nhan-cua-xung-dot-dat-dai-o-viet-nam.html

Statistic Office of Thai Nguyen City. (2018). Report on socio-economic statistics to 2017 (Vietnamese).

Thai Nguyen city portal. (2019, January 6). 10 outstanding achievements of Thai nguyen city in 2018 (Vietnamese). Thai Nguyen City Portal. http://thainguyencity.gov.vn/home/news/?8665/10-THaNH-TuU-NoI-BaT-CuA-THaNH-PHo-THaI-NGUYeN-NaM-2018.htm

Thao, N. T. B. (2015). Acquisition of Agricultural Land for Urban Development in Peri-urban Areas of Vietnam: Perspectives of Institutional Ambiguity, Livelihood Unsustainability and Local Land Grabbing [Okayama University]. http://ousar.lib.okayama-u.ac.jp/files/public/5/53446/20160528 123138493192/K0005164_fulltext.pdf

Thao, P. (2013, September 11). Experiences in land acquisition in the number of countries in the world (Vietnamese). Central Internal Affairs Committee. http://noichinh.vn/ho-so-tu-lieu/201309/kinh-nghiem-thu-hoi-dat-cua-mot-so-quoc-gia-tren-the-gioi-292298/

Thu Hang, V. (2017). Equity issues in land acquisition: a source of delays in large construction projects in Vietnam [Queensland University of Technology]. https://eprints.qut.edu.au/112385/9/Thu_Hang_Vu_Thesis.pdf

Thuan, N. M., Thanh, D. N., \& Tuyen, T. T. M. (2018). Factors influencing households' livelihood satisfaction after land acquisition in Vinh Long province (Vietnamese). Can Tho University Journal of Science, 54(1D), 218-228. https://doi.org/10.22144/ctu.jvn.2018.026

Thuy, T. T. T. (2017). State support to create jobs for farmers whose land is acquired in Hung Yen province (Vietnamese) [Ho Chi Minh National Academy of Politics]. http://tailieudientu.lrc.tnu.edu. vn/chi-tiet/ho-tro-cua-nha-nuoc-nham-tao-viec-lam-cho-nong-dan-bi-thu-hoi-dat-o-tinh-hung-yen-58054.html

Tobler, W. R. (University of M. I. (1970). A Computer Movie Simulating Urban Growth in the Detroit Region. Economic Geography, 46(Jun), 234-240. https://doi.org/10.2307/143141

Tuyen, T., Lim, S., Cameron, M., \& Van Huong, V. (2014). Farmland loss, nonfarm diversification and inequality among households in Hanoi's peri-urban areas, Vietnam. International Development Planning Review, 36(3), 357-379. https://doi.org/10.3828/idpr.2014.20

Land Law, Pub. L. No. 45/2013/QH13, 1 (2013).

World Bank. (2016). Social Assessment Report (The World Bank Financed Yakou Shipping Hub Project). http://documents.worldbank.org/ curated/en/875511477552172804/pdf/SFG2596-REVISED-SA-P158717-Box405297B-PUBLIC-Disclosed-8-21-2017.pdf

Wu, Y.-H. (Eva), \& Hung, M.-C. (2016). Comparison of Spatial Interpolation Techniques Using Visualization and Quantitative Assessment. In M. Hung (Ed.), Applications of Spatial Statistics (pp. 17-34). IntechOpen. https://doi.org/http://dx.doi.org/10.5772/65996

Xo, T. A. (2017). Experience in handling large groups of complaints and denunciations at the Inspector of the Ministry of Public Security (Vietnamese). ThanhtraVietnam. http://thanhtravietnam.vn/ nghien-cuu-trao-doi/kinh-nghiem-xu-ly-cac-doan-kn-tc-dong-nguoi-tai-thanh-tra-bo-cong-an-177597

Yamane, T. (1973). Statistics: An Introductory Analysis (Third). Harper and Row. https://archive.org/ details/statisticsintrod00yama/page/1130/mode/2up

Yen, P. Q., Nga, N. T. T., \& Hanh, T. T. (2019). Research and Experimental Comparison of Topographic Modeling Methods (Vietnamese). VNU Journal of Science: Earth and Environmental Sciences, 35(4), 68-79. https://doi.org/https://doi.org/10.25073/2588-1094/vnuees.4445

Yu, Y., Xu, H., Wang, X., Wen, J., Du, S., Zhang, M., \& Ke, Q. (2019). Residents' willingness to participate in green infrastructure: Spatial differences and influence factors in Shanghai, China. Sustainability (Switzerland), 11(19). https://doi.org/10.3390/su11195396 